\title{
Medullary Paracoccidioidomycosis Treated Successfully with Oral Itraconazole
}

\section{Paracoccidioidomicose medular tratada com sucesso com Itraconazol oral}

\author{
Timóteo A. de L. Almeida ${ }^{1}$ Adroaldo B. Mallmann ${ }^{1}$ Paulo S. Crusius ${ }^{1}$ Charles A. Carazzo ${ }^{1}$ \\ Marcelo U. Crusius ${ }^{1}$ Pedro Biasi ${ }^{1}$ Matheus P. Brunet ${ }^{1}$ Rafael Espanhol ${ }^{1} \quad$ Eduardo F. M. Baldissera ${ }^{1}$ \\ Wellinton Souza ${ }^{1}$ \\ ${ }^{1}$ Department of Neurology and Neurosurgery, Hospital São Vicente \\ de Paulo, Passo Fundo, Rio Grande do Sul, Brazil \\ Address for correspondence Timóteo A. de L. Almeida, MD, Rua \\ Paissandu 1973, Ap 204, Passo Fundo - RS, Brazil \\ (e-mail: timoteo@dr.com). \\ Arq Bras Neurocir 2016;35:352-356.
}
Abstract
Keywords - medullary paracocci-
dioidomycosis
- central nervous system infection

\section{Resumo \\ Palavras-chave \\ - paracocci- dioidomicose medular \\ - infecção do sistema nervoso central}

Paracoccidioidomycosis is the most prevalent endemic mycosis in Latin America, with a great incidence in Brazil. Although a common disease, its medullary form is rare. We present a case report of medullary paracoccidioidomycosis presenting with subacute, progressive, spinal cord symptoms, and with multiple expansive lesions into the cervical and thoracic spinal cord. The patient was treated with itraconazole and showed good clinical and radiologic recovery upon six months of follow-up.

Paracoccidioidomicose é a micose endêmica de maior prevalência na America Latina, com grande incidência no Brasil. Apesar de comum, sua forma medular é rara. Apresentamos um relato de caso de paracoccidioidomicose medular apresentando sintomas subagudos e progressivos na medula, com múltiplas lesões expansivas na medula, cervical e torácica. O paciente foi tratado com itraconazole e apresentou melhora clínica e recuperação radiológica após seis meses.

\section{Introduction}

Paracoccidioidomycosis is a chronic granulomatous infection caused by Paracoccidioides brasiliensis and Paracoccidioides lutzii (a round-to-oval, multibudding yeast form). It is believed that the incidence of Paracoccidioidomycosis ranges between 3 per million to 3 per 100,000 per year. ${ }^{1}$ The disseminated form of the disease commonly affects men in rural areas, between 30 and 50 years of age, from lower social classes, and is the most prevalent endemic mycosis in South America, with its highest inci-

received

September 14, 2015

accepted

December 1, 2015

published online

March 2, 2016

$10.1055 / \mathrm{s}-0035-1571267$ ISSN 0103-5355. dence occurring in Brazil, followed by Colombia and Venezuela. ${ }^{2-4}$

The central nervous system involvement appears as one of two forms: the meningeal form and the granulomatous or pseudotumoral form. The latter is present in more than $10 \%$ of cases, ranging from 1 to $27.7 \%$ in the Brazilian series. ${ }^{5,6}$ It was first described by Pereira and Jacobs in 1919. In turn, the medullary form was described by Braga and Okamura in 1973. ${ }^{7,8}$

We present the case of a 41 -year-old male patient diagnosed with paracoccidioidomycosis with the involvement of

Copyright @ 2016 by Thieme-Revinter

Publicações Ltda, Rio de Janeiro, Brazil

License terms

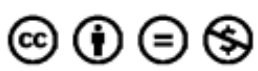


the spinal cord, and treated with itraconazole showing a good outcome.

\section{Case Report}

A 41-year-old man, military police, presented to our service referring paresis of the left lower limb, crural paraparesis, as well as ataxia. He denied fever and had no other complaints. His medical history was marked by prior smoking (20 packs/ year) but was currently abstinent, without other comorbidities. There was nothing noteworthy in his family history. Moreover, he denied contact with any suspected lung disease patient.

The patient was in a good general condition and his neurological exam showed a left lower limb paresis grade IV, crural paraparestesia for light tactile stimulation, bilateral patellar hyperreflexia, Hoffmann sign in the left upper limb and sensory ataxia.

Cervical and thoracic spine magnetic resonance imaging (MRI) showed two isointense lesions on T1-weighted images, with hyperintense perilesional halo and hyperintense spinal cord signal suggestive of myelopathy on T2-weighted images, and homogeneous enhancement after gadolinium administration (-Fig. 1). A chest radiography performed upon admission revealed diffuse micronodules of the bilateral lung parenchyma, while a tomographic scan of the chest showed diffuse bilateral micronodules and typical groundglass attenuation, suggesting fungal infection (-Fig. 2). The study of cerebrospinal fluid and general serum tests were both nonspecific. The patient received dexamethasone, with partial recovery of his deficit.

The patient was then submitted to a bronchoscopic lung biopsy. Histological analysis of the lung tissue showed a "non-necrotizing granulomatous pneumonia," with negative fungus and acid-fast bacilli research, putting in question the possibility of hypersensitivity or sarcoidosis. Due to the anatomopathological non-specificity and the radiological exams suggestive of fungal disease, the patient began drug treatment for paracoccidioidomycosis. Since he was in good overall condition, showing no weight loss or

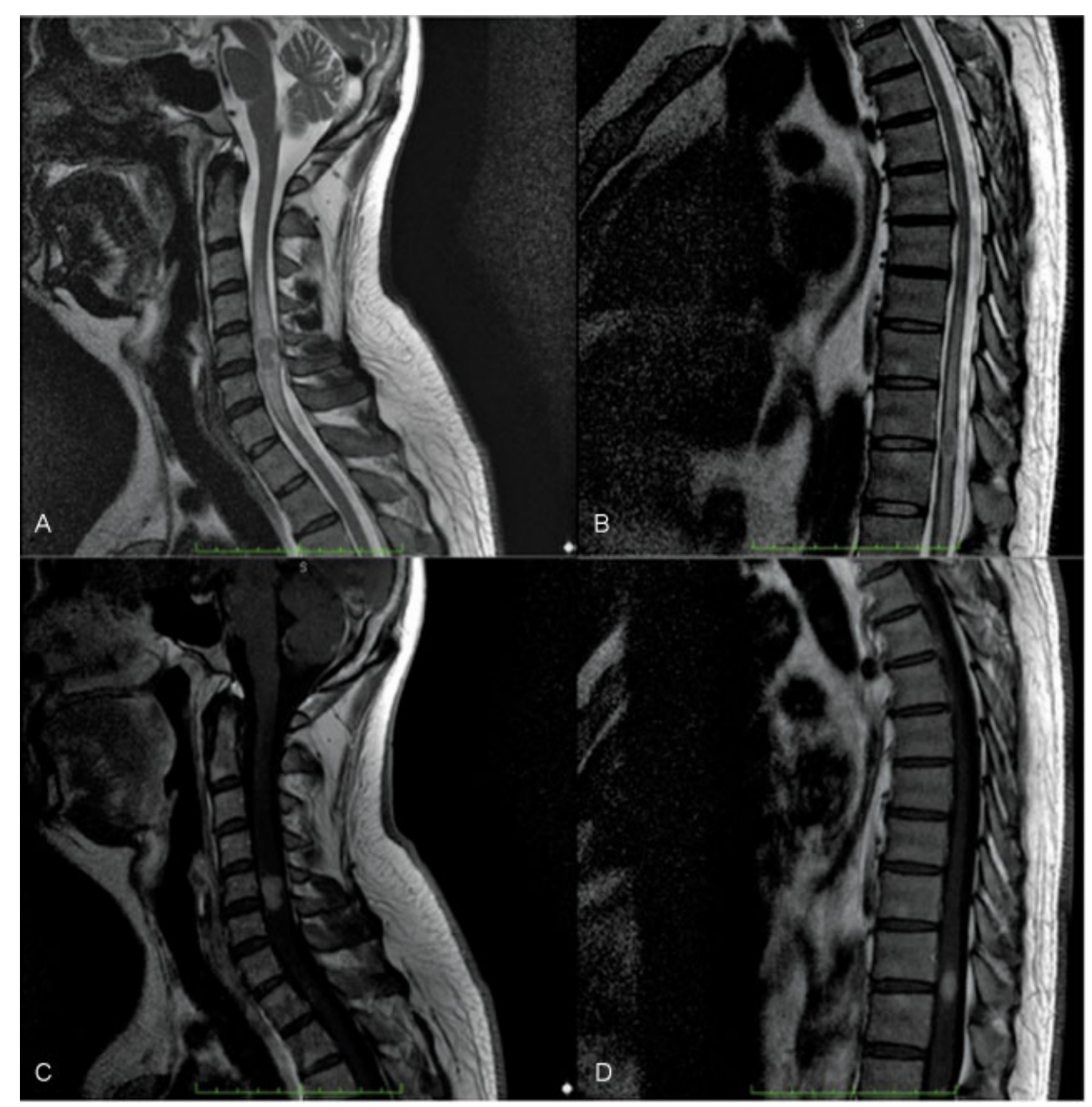

Fig. 1 MRI scan performed at admission shown an isointense lesion with a hyperintense halo and sign of myelopathy at T2-weighted sequence of the cervical (A) and thoracic (B) regions. After gadolinium administrations we observe homogeneous enhancement of both lesions (C and D). 


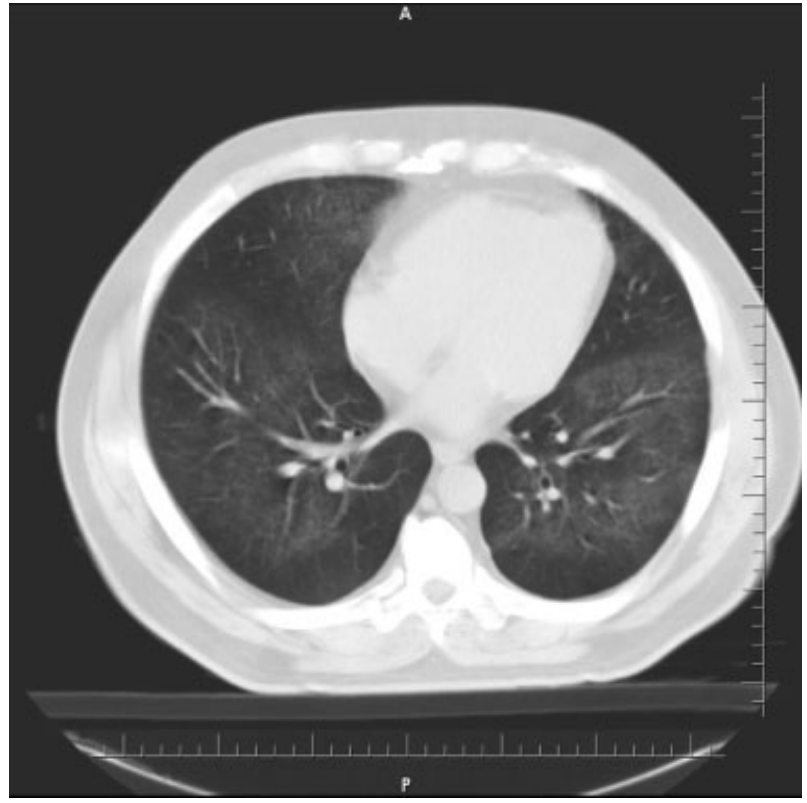

Fig. 2 Chest CT scan showing typical ground-glass attenuation of both lungs, suggestive of pulmonary paracoccidioidomycosis.

ventilatory distress, and his symptoms were less intense after corticosteroids, we decided to initiate treatment with itraconazole.

The patient gradually improved clinically, with improvement of strength in his left leg, and started walking with assistance by the end of a week of treatment. Chest radiography at the end of first week of treatment also showed improvement. After 13 days of treatment, we identified $P$. brasiliensis growth in the cultured lung tissue.

During the treatment, he developed a pain syndrome in his legs, being treated with amitriptyline and gabapentin. MRI scan of the cervical and the thoracic spine regions at two weeks and at one month after the start of treatment showed gradual improvement of the lesions.
We performed a control MRI scan six months after the treatment, which showed complete resolution of the lesions on T2-weighted images of the cervical and the thoracic spine regions, with small residual gliosis (-Fig. $\mathbf{3}$ ).

\section{Discussion}

Neuroparacoccidioidomycosis is a rare disease of difficult diagnosis, with a mortality rate greater than $50 \%$ in some studies, with almost all the reported cases consisting of surgical or autopsy findings. ${ }^{2,5} \mathrm{~A}$ recent study of 422 patients with paracoccidioidomycosis diagnosed between 1980 and 1999 presented six cases (1.4\%) of central nervous system involvement, two of them in the spinal cord. Paniago et al reported a series of 13 cases of neuroparacoccidioidomycosis while spinal cord involvement was present in 4 patients $(30.7 \%)^{9}$

In a systematic review from 2009, there were 257 cases in 81 studies (Medline / Lilacs) on neuroparacoccidioidomycosis. ${ }^{10}$ Out of these patients, $93 \%$ were men, with chronic granulomatous form being the most frequently encountered. Spinal cord involvement was reported in $9.2 \%$ of these cases, with predominance of the thoracic segment. The diagnosis was confirmed by biopsy in $57.2 \%$ and the cerebrospinal fluid (CSF) analysis contributed to the diagnosis in only $16.3 \%$ of such cases. The higher prevalence of disease in men could be explained by the inhibitory action of estrogens on the transformation of the conidia to the yeast form. ${ }^{11}$

Neuroparacoccidioidomycosis diagnosis is difficult because of nonspecific changes in routine exams. CSF analysis may show mild pleocytosis or high protein concentration. The direct examination of the CSF rarely demonstrates $P$. brasiliensis. ${ }^{5}$ Studies with gp 43 and gp70 antigen in serum or CSF showed high sensitivity in patients with neuroparacoccidioidomycosis. In our case, chest radiography helped us in achieving the correct diagnosis with demonstration of suggestive findings of fungal infection. ${ }^{3}$

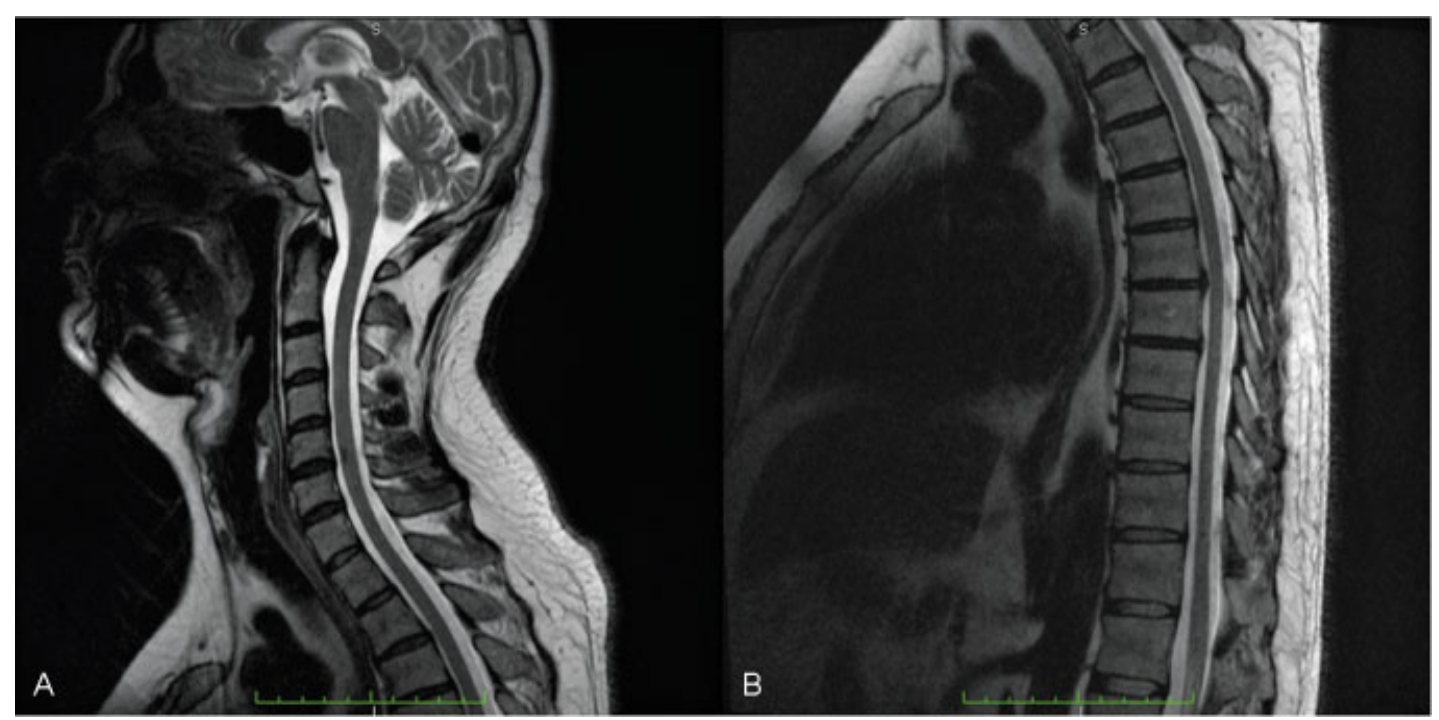

Fig. 3 MRI scan 6 months after treatment showing the complete remission of the lesions on T2-weighted images of the cervical and thoracic spinal cord. 
The MRI scan is characterized by a variable signal on T1weighted images and hypointense signal on T2-weighted images, with peripheral edema and nodular or ring enhancement after contrast administration. ${ }^{10,12}$ The main differential diagnosis is with intramedullary tumor which may present similar radiological patterns. In the patient described in this report, the shape and multiplicity of lesions helped in the diagnosis and therapeutic decision, which led us to think of an inflammatory or infectious disease as a possible diagnosis. Evolutive computed tomography (CT) scan in patients with neuroparacoccidioidomycosis showed disappearance of the lesions in $30.8 \%$, reduction of lesions in $15.4 \%$, and no change in $38.5 \%{ }^{2}$ In addition to the standard neuroradiological scans, micronodules on chest radiography also suggested the hypothesis of fungal disease as a possible etiology.

In the Pubmed and LILACS databases we found thirteen reports describing eighteen cases of medullary paracoccidioidomycosis. We also found one case not indexed in the two databases, the first case being of medullary infection by Paracoccidioides brasiliensis described in the literature, and one case of extradural spinal cord compression. ${ }^{2,4,6-10,12-17}$ Of the nineteen cases described, the majority underwent laminectomy and approach to the expanding lesion. The medical treatment used anfotericin B in three cases, anfotericin plus sulfadiazine in one case, only sulfadiazin in two cases, sulfamethoxazole plus trimethoprim in two cases, sulfamethoxazole plus trimethoprim plus fluconazole in one case, only fluconazole in one case, and cetaconazole in one case. In eight cases, we could not find the drug of choice. Functional recovery was poor or unchanged in the majority of the cases described.

As we note in almost all the reports of medullary paracoccidioidomycosis, the majority of the patients undergo neurosurgical procedure, with the correct diagnosis appearing after the anatomopathological analysis. The outcome would probably be better if the correct diagnosis could be performed previously and the treatment started as soon as possible.

We found reports of pain during the drug treatment, similar to that presented by our patient, which was considered to be due to inflammatory reaction exacerbated by the death of the fungus. ${ }^{16}$ In the present case, we treated the patient with amitriptyline and gabapentin, also showing good result.

The treatment of systemic paracoccidioidomycosis is based on the severity of the disease. Itraconazole $200 \mathrm{mg}$ per day for adults, for a period of 6 to 18 months or sulfamethoxazole plus trimethoprim $800 / 160$ or $1200 /$ $240 \mathrm{mg}$ twice a day for 12 to 24 months is recommended for mild to moderate cases, while anfotericin B or IV sulfamethoxazole plus trimethoprim is indicated for severe disease until clinical improvement. For central nervous system disease it is recommended to treat as a severe disease, without specifying intracranial or medullary cases. The serology analysis is highly recommended not only for diagnosis but also for follow-up, preferably at a level inferior to 1:2 of anti-P. brasiliesis antibodies after treatment. ${ }^{1}$

Some authors advocate surgical treatment in neuroparacoccidioidomycosis for cases in which the granuloma is accessible, in which the symptoms do not show improve- ment with medical treatment, or in which a quick solution to the problem becomes necessary with early surgical treatment being recommended in the case of progressive spinal cord compression. ${ }^{17}$ We also found a recent report of a patient with cerebral neuroparacoccidioidomycosis treated with intralesional therapy with amphotericin B for 4 weeks with satisfactory results. ${ }^{6}$

\section{Conclusion}

Medullary paracoccidioidomycosis is a rare condition, with only nineteen cases described in literature. It is difficult to diagnose with potentially high morbidity and mortality. As the literature review suggests, clinical suspicion is the most important point for the correct diagnosis and optimal therapeutic management in patients afflicted by the condition.

We presented a case of medullary paracoccidioidomycosis with good results after treatment with oral itraconizol, with evidence of functional and radiological recovery. In this report, the main differential diagnosis was with intramedullary tumor, which may present a similar clinical and radiological presentation, making it difficult to define the correct diagnosis.

Early diagnosis and appropriate treatment are critical for a functional recovery of these patients.

\section{Disclosure}

The authors report no conflict of interest concerning the materials or methods used in this study or the findings specified in this paper.

Author contributions to the study and manuscript preparation include the following. Conception and design: Almeida and Mallmann. Acquisition of data: Almeida. Analysis and interpretation of data: Almeida and Mallmann. Drafting the article: all authors. Critically revising the article: all authors. Reviewed submitted version of manuscript: all authors. Approved the final version of the manuscript on behalf of all authors: Almeida.

\section{References}

1 Shikanai-Yasuda MA, Telles Filho FdeQ Mendes RP, Colombo AL, Moretti ML. [Guidelines in paracoccidioidomycosis]. Rev Soc Bras Med Trop 2006;39(3):297-310

2 Fagundes-Pereyra WJ, Carvalho GTC, Góes AM, das Chagas Lima e Silva F, de Sousa AA. [Central nervous system paracoccidioidomycosis: analysis of 13 cases]. Arq Neuropsiquiatr 2006;64 (2A):269-276

3 Minguetti G, Madalozzo LE. Paracoccidioidal granulomatosis of the brain. Arch Neurol 1983;40(2):100-102

4 Paniago AMM. Paracoccidioidomicose: estudo clínico e epidemiológico de casos atendidos no HU-UFMS [dissertation]. Campo Grande (MS): Instituto Oswaldo Cruz/UFMS; 2000

5 Lorenzoni PJ, Chang MR, Paniago AMM, Salgado PR. [Paracoccidioidomycosis meningitis: case report]. Arq Neuropsiquiatr 2002; 60(4):1015-1018

6 Teixeira MJ, Fonoff ET, Machado LdosR, Nóbrega JPS, StermanNeto H, Amorim RL. Paracoccidioidomycosis: intralesional therapy. Arq Neuropsiquiatr 2010;68(3):458-459 
7 Pereira JM, Jacobs F. Um caso de blastomicose com acessos epilepticos. An Paul Med Cir 1919;10:217-219

8 Braga FM, Okamura M. Blastomicose medular. Seara Med Neurocir 1973;1:435

9 Paniago AM, de Oliveira PA, Aguiar ES, et al. Neuroparacoccidioidomycosis: analysis of 13 cases observed in an endemic area in Brazil. Trans R Soc Trop Med Hyg 2007;101(4): 414-420

10 Pedroso VSP, Vilela MdeC, Pedroso ERP, Teixeira AL. [Paracoccidioidomycosis compromising the central nervous system: a systematic review of the literature]. Rev Soc Bras Med Trop 2009;42(6):691-697

11 Sano A, Miyaji M, Nishimura K. Studies on the relationship between paracoccidioidomycosis in $\mathrm{ddY}$ mice and their estrous cycle. Mycopathologia 1991;115(2):73-81

12 Magalhães AC, Bacheschi LA, Caramelli P, et al. [Paracoccidioidomycosis of the central nervous system: study of 5 cases by magnetic resonance]. Rev Hosp Clin Fac Med Sao Paulo 1993; 48(2):94-97

13 Lutz A. Uma micose pseudo-coccidea localizada na nuca e observada no Brasil: contribuição ao conhecimento das linfoblastomicoses americanas. Bras Med 1908;22:121-124

14 Francesconi F, da Silva MT, Costa RL, et al. Long-term outcome of neuroparacoccidioidomycosis treatment. Rev Soc Bras Med Trop 2011;44(1):22-25

15 Pacheco RAB, Arruda WO, Hunhevicz SC, Tsubouchi MH, Torres LFB. Thoracic intraspinal Paracoccidioidomycosis. Case report. Arq Neuropsiquiatr 1996;54(3):474-478

16 Moura LPM, Raffin CN, del Negro GMB, Ferreira MS. Paracoccidioidomycosis evidencing spinal cord involvement successfully treated by fluconazole. Arq Neuropsiquiatr 1994;52(1):82-86

17 Colli BOC, Assirati Júnior JA, Machado HR, et al. Intramedullary spinal cord paracoccidioidomycosis. Report of two cases. Arq Neuropsiquiatr 1996;54(3):466-473 